\title{
The Effects of Service Quality on Customer Trust and Satisfaction in Internet Banking
}

Eduardo Torres-Moraga

Escuela de Economía y Negocios

Universidad de Chile

eduardot@fen.uchile.cl

Cristóbal Barra

Escuela de Economía y Negocios

Universidad de Chile

cbarra@fen.uchile.cl

Arturo Z. Vásquez-Parraga

College of Business Administration

University of Texas Pan-American

avasquez@utpa.edu

Antonio Farías

Escuela de Economía y Negocios

Universidad de Chile

anfari@fen.uchile.cl

\begin{abstract}
Purpose - This study contributes a multidimensional measure of service quality impacting on the trust and satisfaction of customers using internet banking.

Design/methodology/approach - Unlike previous studies reporting on independent factors of service quality affecting customer trust
\end{abstract}


and satisfaction, this study elaborates and tests a multidimensional measure of service quality in the context of internet banking services. In addition, this study tests a proposed model and rival models showing how service quality impacts on customer trust and satisfaction.

Findings - Service quality is a second-order factor with 6 dimensions revealing 6 important characteristics of the service quality that is expected in Internet banking. They are not separate characteristics of service quality but dimensions of a construct. The proposed model showing a direct impact of service quality on satisfaction and an indirect one on trust is the best tested model using structural equations.

Research limitations/practical implications: The research limitations and practical implications of the results are discussed.

Originality/value - The study elaborates and tests a multidimensional measure that is a comprehensive, and at the same time, parsimonious, approach to service quality when explaining customer trust and satisfaction in internet banking services.

Keywords: Internet banking, Multidimensional service quality, Customer trust, Satisfction.

\section{Resumen}

Objetivo - Este estudio muestra el impacto de una medida multidimensional de la calidad del servicio respecto de la confianza y la satisfacción de los clientes que usan servicios de banca por internet.

Diseño/metodología - De manera distinta a estudios previos que se basan en los efectos independientes de los factores de la calidad del servicio acerca de la confianza y la satisfacción, este estudio presenta y prueba una medida multidimensional de calidad del servicio en la banca por internet. Además, se prueban modelos alternativos rivales que muestran cómo la calidad del servicio genera un impacto en la confianza y la satisfacción.

Resultados - La calidad del servicio es un factor de segundo orden con seis dimensiones que revelan seis importantes características para la gestión en la banca por internet. Estas no son características independientes, sino dimensiones de un constructo. El modelo propuesto que muestra un impacto directo de la calidad del servicio 
en la satisfacción y uno indirecto en la confianza, es el mejor modelo probado mediante ecuaciones estructurales.

Valor - El estudio propone y prueba una medida de calidad del servicio que es comprehensiva, pero al mismo tiempo parsimoniosa, que permite entender el efecto conjunto de las dimensiones que la componen respecto de la confianza y la satisfacción en el contexto de la banca por internet.

Palabras clave: Banca por internet, calidad del cervicio, confianza, satisfacción.

\section{Introduction}

This research focuses on the role of service quality in customer trust and satisfaction in the context of Internet bank services. Internet banking is increasingly used to adapt selling and servicing to new and changing customer needs. Indeed, the Internet is pivotal in recent changes in the banking industry. Banks use the Internet to operate outside their physical locale (Howcroft and Durkin, 2000; Mols, 1999), cut costs (Humphreys, 2000), offer highly customized services (Dannenberg and Kellner, 1998), innovate (Prescott and van Slyke, 1997), foster greater understanding of the customer (Yiu et al., 2007), and/or develop side businesses and increase the customer base (Sohail and Shaikh, 2008).

Such benefits to the business, however, have been neither free nor cheap to banks and customers. The implementation of services online has increased the service complexity for bank administration while simultaneously introducing greater uncertainty and risk for the users. In fact, some current deficiencies in the banking system belong to the new process, such as the lack of personal interaction between the bank and its customers and the twilight zone created in the use of customer information, particularly the information considered private and sensitive (Casaló et al., 2007). 
Consequently, there is a need to reduce bank complexity and reduce customer risk in the Internet banking environment. There is a need to increase trust between the parties. A greater trust between the bank and its customers may contribute toward diminishing the impact of drawbacks of Internet banking by offsetting the effect of customer perceived risk in an atmosphere that is more vulnerable than traditional banking (Pavlou, 2003). Logically, banks are interested in knowing and using the drivers of customer trust in Internet banking so that they can be more effective in reaching customers and gaining their loyalty. Panel data research shows that customers become more loyal, in terms of repeated purchase, after they adopt online banking (Hitt et al., 2008).

Service quality and its influence in customer trust has been studied in the contexts of transactional relationships (Sharma and Patterson, 1999; Zaichkowsky, 1985) and e-Commerce (Harris and Goode, 2004; Hwan and Kim, 2007; Zeithaml et al., 1996), but it has received little attention in the context of Internet banking (Cha et al., 2005). Studies in e-Commerce, for instance, identify a number of variables that constitute service quality and that influence customer trust: structural assurance (Gefen et al., 2003; McKnight and Chervany, 2001; McKnight et al., 2002), usability (Casaló et al., 2007; Flavián et al., 2006), perceived ease of use (Suh and Han, 2002), access (Liu et al., 2005), information quality (Kim et al., 2008), and content quality (Liao et al., 2006). A logical question follows: can the aforementioned variables form part of a multidimensional construct of service quality (Cox and Dale, 2001; Liu and Arnet, 2000; Walczuch and Lundgren, 2004; Yiu et al., 2007) which in turn may influences trust? If so, it is expected that such variables, interacting with other components of service quality, would influence customer trust differently than when considered separately.

A final concern is how both variables, service quality and trust, are related, directly or indirectly. Existing studies support both relationships. However, if the relationship is indirect, the question is 
what mediates the relationship. Some authors have already concluded that it is mediated by customer satisfaction (Cáceres and Paparoidamis, 2007).

A literature review on customer trust, service quality, and customer satisfaction precedes the formulation of key hypotheses for the study. A methodology section addresses the instruments, data collection and the important issues of validity, reliability, and dimensionality of the constructs. The results section provides an account of hypotheses testing using structural equation modeling. The tested model is compared to rival models to probe the robustness of the proposed model. The conclusions and the managerial implications of the outcomes are presented last.

\section{Literature review}

\section{A. $\quad$ Customer trust in online services}

Trust is a key concept in relational marketing (Crosby et al., 1990; Doney and Cannon, 1997; Macintosh and Lockshin, 1997) and has been studied from several perspectives (Gefen et al., 2003). A definition of trust widely accepted and used underscores the willingness of the trusted counterpart in the exchange relationship to reciprocate (Moorman et al., 1992).

Trust in an online service context may not be essentially different from trust in a traditional service context (Kracher et al., 2005) despite the fact that an online service context involves a distant relationship between the user and the provider and lacks human intermediaries (Yoon, 2002). A distant relationship limits the user's ability to provide immediate feedback and to adequately learn and manage the use of an online system (Nohria and Eccles, 1992). Understandably, the web site is the seller in e-Commerce (Jarvenpaa and Tractinsky, 1999), whereas in a normal relationship, people trust people, not machines (Solomon and Flores, 2001). In addition, 
eCommerce customers may feel vulnerable to the service provider's proposition (Pavlou, 2003) and/or to the technologically driven information on the web (Kato et al., 2008). Information and communications technology increases credibility risk and requires effective management of information-credibility risk (Hirose and Sonehara, 2008). Thus, obtaining customer trust in e-Commerce is more challenging than getting it in traditional exchanges.

Trust in eCommerce or e-Trust is defined as the degree of trust customers experience in online exchanges or online channel exchanges (Ribbink et al., 2004). More specifically, e-Trust rests on three customer perceptions of the provider (Suh and Han, 2002): 1) integrity, the user's belief that the provider acts out of good will, acts ethically (such as being truthful) and keeps his promises; 2) benevolence, the user's belief that the provider seeks the user's benefit beyond his own interests or egocentric motives; and 3) ability, the user's belief that the provider has the power to bring about what the user needs.

Trust has a more important role in online exchanges than in traditional exchanges (Ratnasingham, 1998) mainly because it takes place in a more uncertain environment (Pavlou, 2003), it lacks human interface in online transactions (Papadopoulou et al,. 2001; Torres et al., 2008), and it represents greater customer risk due to the absence or complexity of contracts and guarantees (Crosby et al., 1990; Grazioli and Jarvenpaa, 2000). Reasonably, users of online transactions have more difficulty in evaluating provider commitments and the provider's use of customer personal information (McKnight et al., 2002). Yet, the rational expectation is that trust in online transactions can reduce customer perceived risk (Pavlou, 2003) and influence customer loyalty (Macintosh and Lockshin, 1997), resulting in repeated purchase in the near future. 


\section{B. $\quad$ Service quality in online services}

Quality, in general, is conceived as a bundle of proprieties, circumstances, characters, attributes, traits, and other human valuations, inherent or acquired, that are valued distinctively from other evaluations (Maqueda and Llaguno, 1995). Service quality relates to quality in service exchanges or, more specifically, to customer conformity with the service as specified by the user (Parasuraman et al., 1988).

Measuring service quality has become relevant in marketing since the 1980's. One of the first proposals was SERVQUAL (Parasuraman et al., 1988). Using five dimensions and 22 items, this instrument became quite useful in various industries and, with some adaptations, in some services (Carman, 1990). In turn, SERVPERF was introduced by Cronin and Taylor (1992) with three dimensions (functional quality, technical quality, and corporate image). Later, in the context of information systems, IS-SERVQUAL (Kettinger and Lee, 1999) was developed to measure service quality in this area. However, none of these instruments is considered appropriate for electronic or Internet services mainly because some of the measures used require a direct human exchange, such as empathy (Janda et al., 2002).

Thus, new instruments were developed for electronic services. The first one used five dimensions: service, information quality, system, degree of enjoyment, and web design (Janda, Trocchia and Gwinner, 2002). WebQual is based on 12 dimensions and centered on the technical quality of web sites (Loiacono et al., 2007). SiteQual consists of nine items grouped in four dimensions: easy use, design, accessibility, and interaction (Yoo and Donthu, 2001), but ignores the customer's perceptions of the buying process (Sohail and Shaikh, 2008). eTailQ used focus groups to develop service quality both online and offline, and propose 14 items grouped in four dimensions: web site design, reliability, privacy/security, and customer service (Wolfinbarger and Gilly, 
2003). In addition, van Riel et al. (2001) propose scales centered on web medical information and three factors: central service, support service, and user interface, and Barnes and Vidgen (2002) put forth WEBQUAL 4.0 with three dimensions: web site usability, information quality, and service interaction.

More specifically, there are instruments that measure service quality in online shopping sites. Madu and Madu (2002) propose one with 15 dimensions; Zeithaml et al. (2000) set forth ESERVQUAL with 11 dimensions; Cox and Dale (2001) offer an instrument with six constructs (accessibility, communication, credibility, understand-ding, appearance, and availability); Yang et al. (2005) study perceived quality in various web sites and arrive at five dimensions: usability, utility, information adequacy, accessibility, and interaction; Parasuraman et al., (2005) put forward E-S-QUAL with 22 items (similar to SERVQUAL) grouped in four dimensions: efficiency, availability, privacy and actualization; Parasuraman et al., (2005) also introduce E-RecS-QUAL with three dimensions (response capability, compensation and contact) to include customers that are in the process of service recovery.

The following characteristics of service quality in electronic commerce are common ground in previous literature (Sohail and Shaikh, 2008): privacy/security, web availability and content, web design, usability, and reliability. Yet, such common ground can only be suggestive of potential characteristics of Intent banking. Thus, a specific construct of service quality for Internet banking has to be developed on the basis of the more generic measures applied in electronic commerce.

From this perspective, when measuring the influence that service quality might have on the other variables, it is imperative to consider service quality as a multidimensional construct rather than considering its dimensions separately. Several studies have done the latter in the context of e-commerce, relating some variable components of service quality directly with trust, for example, structural assurance (Gefen et al., 2003; McKnight and Chervany, 
2001; McKnight et al., 2002), usability (Casaló et al., 2007; Flavián et al., 2006), access (Liu et al., 2005) and content quality (Liao et al., 2006).

\section{Customer satisfaction in online services}

Customer satisfaction generally refers to consumers' affective state resulting from the long-term evolution of their relationship with a provider (Sanzo et al., 2003). Such a state can be seen in two ways, an affective predisposition linked to an economic process or a psychological view of how promises are fulfilled (Geyskens et al., 1999).

A measure of customer satisfaction in services requires a comparison between consumer's expectations, before a service is used, and the effective performance in the service delivery which is evaluated a posteriori (Oliver, 1999). Thus, it can also be said that satisfaction is the evaluation of a gap between two stimuli, a result and a referent for comparison (Oliver, 1997).

In an offline context, customer satisfaction is produced in the personal interaction between the consumer and the provider while service is performed (Bitner et al., 1990). In an online context, however, services are provided without personal interactions (Szymanski and Hise, 2000). From this perspective, e-satisfaction may result from the comparison between users' experience with Internet service and their experiences with traditional commerce (Szymanski and Hise, 2000).

Internet has some advantages when used as self-service technology: convenience, saving time and money, avoiding interpersonal interaction, and being in control. These are advantages that can become drivers of satisfaction in an online context or esatisfaction (van Riel et al., 2001). E-satisfaction can switch users from traditional to online services in addition to lengthening 
customer Internet usage and increasing customer references and recommendations for Internet usage (Bansal et al., 2004).

E-satisfaction in Internet banking seems to be influenced not only by the compatibility between the technologies used by the customer and the provider (Torres et al., 2008), but also the availability of information and security in the transactions at the bank (Bansal et al., 2004). The latter factors pertain to service quality as well.

\section{Key relationships}

As evident by reviewing the literature, service quality is a multidimensional construct comprised of interdependent variables. From this perspective, the effect that each of the variables has on trust does not occur in an isolated manner, but rather is influenced by all other variables in the construct. Considering this interrelationship, the effect of the components of service quality on trust should not be measured independently but rather measured within service quality as a multidimensional construct.

From this point of view, the effect of service quality on trust is not direct; it should be mediated by satisfaction, in line with the considerations presented in the specialized literature. Consequently, this study considers the following hypothesis.

\section{A. Customer satisfaction and customer trust}

Customer satisfaction is a key antecedent of various outcomes in relational marketing, such as trust (Selnes, 1998), commitment (Dimitriades, 2006), and reputation (Selnes, 1993). Similar relationships seem to take place in e-Commerce (Evanschitzky et al., 2004), where satisfaction seems to also influence customer loyalty in terms of re-use intention and positive mouth-to-mouth 
communication (Bansal et al., 2004; Anderson and Srinivasan, 2003). In an online context, satisfaction may also generate better relationships between the firm and its customers (Rust and Lemon, 2001).

Several studies have shown that customer satisfaction influences customer trust in electronic commerce (Harris and Goode, 2004; Hwan and Kim, 2007). In addition, Walczuch and Lundgren (2004) found that both satisfaction and communication positively affect trust in online services, and Pavlou (2003) found a similar result in the context of e-tailer, which was corroborated by Ribbink et al., (2004). Thus, we present the following hypothesis:

H1: The greater the user satisfaction with his/her Internet bank, the greater the user trust in his/her Internet bank.

\section{B. Service quality and customer satisfaction}

The first task in this examination is whether service quality and customer satisfaction are different concepts. Some researchers doubt that they are different (Grönroos, 1984), but others consider them clearly different (Carman, 1990; de Ruyter and Bloemer, 1997; Lee et al., 2000). Service quality and perceived service quality are fundamentally cognitive evaluation, whereas, customer satisfaction is fundamentally an affective evaluation on the basis of personal experiences and sentiments (Floh and Treiblmaier, 2006). Similarly, high quality is related to the customer high expectations, whereas satisfaction is related to experiences in virtual environments (Bauer et al., 2005).

In traditional commerce, it is widely accepted that service quality is an antecedent of customer satisfaction and loyalty (Cronin and Taylor, 1992). Szymanski and Hise (2000) and van Riel et al. (2004) agree that service quality has a direct effect on customer satisfaction in online environments. Additional empirical research 
shows that service quality is also related to customer satisfaction and lower prices in e-Commerce transactions (Mahajan et al., 2002; Reibstein, 2002; Shankar et al., 2003). The relationship of service quality-customer satisfaction has also been ascertained in both conventional banking (Al-Hawari and Ward, 2006) and Internet banking (Sohail and Shaikh, 2008). Thus, we present the following hypothesis:

H2: The higher the service quality of Internet bank services, the greater the user satisfaction with his/her Internet bank.

\section{Methodology}

\section{A. $\quad$ Measures}

The measures for customer trust and customer satisfaction are based on previous research. The measures for e-trust were adapted from Kumar et al. (1995), Doney and Cannon (1997) and Roy et al. (2001). The measures for satisfaction were adapted from Sharma and Patterson (2000), Brockman (1998), Smith and Barclay (1997) and Veloutsou et al. (2004).

The measures for service quality were developed on the basis of the pilot study and the contributions reviewed above (see Appendix). This work resulted in six dimensions for a multidimensional construct of service quality in Internet banking: accessibility/availability, accuracy, product/service quality, responsiveness, security/privacy, and usability. A brief definition of each follows:

- Accessibility/Availability (AA): It refers to the availability and correct functioning of the web site when accessed. 
- Accuracy (AC): It requires that the contents, interfaces and transactions in the web site can be done without errors.

- Product/Service Quality (PQ): It refers to the quality and variety of products offered by the bank through the internet.

- Responsiveness (RE): It relates to the banks' effective capability to respond to customers' requests, and to handle users' problems through the internet.

- Security/Privacy (SP): It relates to a user's perception of how personal information is protected and how structurally safe is the web site.

- Usability (US): It represents the effort that must be made to navigate through the bank's web site or the easy of navigation when using Internet banking.

All six dimensions measure service quality in Internet banking and are supported in part in Wolfinbarger and Gilly (2003), Kim and Pradhakar (2004), Ranganathan and Ganapathy (2002), Parasuraman et al. (2005), Roy et al. (2001), Lin et al. (1997), Brown and Buys (2005) and Gounaris et al. (2003). Usability and security have been often reported in other studies. The other dimensions are backed by lower levels of empirical research. Previous research also shows that some dimensions are independently linked to customer trust, such as usability (Casaló et al., 2007; Flavián et al., 2006), access (Liu et al., 2005), content quality (Liao et al., 2006), and structural assurance (McKnight et al., 2002; McKnight and Chervany, 2001; Gefen et al., 2003).

The items were written as assertions to be evaluated by the respondent using a seven-point Likert scale (anchored at $1=$ completely disagree and $7=$ completely agree), and organized in a questionnaire format (see Appendix). 


\section{B. Pilot study}

Scale development and/or adoption required a pilot study. On the basis of 124 in-depth interviews, feedback was obtained using the Critical Incident Technique (CIT) and following the suggested requirements by Bitner et al. (1990). The technique was instrumental to identifying relevant dimensions and traits in service quality in conditions of positive and negative customer experiences with services provided by Internet banking. Because some interviewees indicated more than an incident, the unit of analysis became the incident, not the interviewee (Jun and Cai, 2001). Each incident had to fulfill the following requirements: (a) Involve an interaction between the bank web and the customer; (b) Obtain service satisfaction or dissatisfaction from the customer perspective; (c) Be a discrete episode; (d) Offer enough detail to be detected and described by the interviewee.

The scale items for each dimension were developed and analyzed using the criteria and procedures recommended by De Wulf and Odekerken-Schröder (2003) as follows:

1) Unidimensionality is tested using factorial analysis of principal components with loadings greater than 0.65 .

2) Convergent validity is tested using fit indices that are statistically significant at a 0.05 confidence level and $\mathrm{R}^{2}$ coefficients that are greater than 0.50 .

3) Construct reliability is measured using Cronbach Alpha with a minimum value of 0.70 and a composite reliability coefficient above 0.60 .

4) Discriminant validity is tested comparing the Chi-squared differences and the AVE index with a value above 0.50 . Each 
construct variance must be greater than the corresponding variance of measurement error.

Current users (organized in focus groups) and executives from selected banks offering Internet banking provided feedback to accomplish two objectives: add items that reflect the concept more clearly and eliminate the items that do not fit in the dimension or construct. Following a method recommended by Zaichkowsky (1985), each expert classified each item in a dimension using three levels of representation: clearly representative, somewhat representative or not representative.

The chosen items reflected a high level of consensus among the participants (Lichtenstein et al., 1990). To make a final decision on the dimensions, Internet bank executives were consulted, and the results of the discussions with them taken into account. Finally, the questionnaire was pre-tested for comprehension, possible ambiguities, and easy evaluation of the scale items with a group of 15 customers.

\section{Sample and data collection}

The sample frame includes users of both virtual banks, those without physical offices for their customers, and conventional banks that offer Internet services as recommended by López (2001). A probabilistic sampling generated a total of 640 complete responses from bank users who have Internet banking at their disposal, who accepted a telephone interview, and who answered the questionnaires administered during the last two months of 2007 in Santiago, the capital city of Chile. Specialized software allowed a random selection of the telephone numbers and the order of the questions, so as to count on a probabilistic sample of bank users.

A brief description of the sample follows. More than half $(55.8 \%)$ have used bank services for four years or less, whereas less 
than half $(44.2 \%)$ for more than four years. Most users $(72.3 \%)$ prefer access to bank services from home, whereas $46.3 \%$ enjoy access from work, 5.9\% get access from leased facilities like Internet cafes, and 3.2\% conduct Internet transactions from other facilities (house of a relative or university) or using a cellular phone. Demographically, $50.2 \%$ are women, $51.5 \%$ are young adults (18-34 years old), $79.1 \%$ have college education whereas $19.5 \%$ have technical education and $10.8 \%$ have not attended college. Finally, about $52 \%$ earn more than $\$ 20,000$ annually whereas $48 \%$, up to $\$ 20,000$ only.

\section{Results}

A. Measurement validity, reliability, and dimensionality

This section examines the dimensionality, reliability and validity of a multidimensional construct for service quality and unidimensional constructs for both customer trust and customer satisfaction and evaluates the same requirements for the entire model.

\section{a. SERVICE QUALITY: MULTIDIMENSIONAL CONSTRUCT}

Exploratory factor analysis using principal components, varimax rotation, eigenvalues greater than one, significant explained variance and factor weights greater than 0.5 (Hair et al., 2005) resulted in six factors for service quality, each factor representing an expected dimension: responsiveness, security/privacy, accessibility/ vailability, usability, accuracy, and product quality.

Confirmatory factor analysis using structural equation modeling and software EQS 6.1 considered strengthening the factors and improving the model (Hair et al., 2005) by applying the three criteria recommended by Jöreskog and Sörbom (2001). Yet, the 
resulting factors did not need improvement because they already showed high reliability, strong convergence with the corresponding latent variable, and an $\mathrm{R}^{2}$ greater than 0.3 . The resulting measurement model shows good fit to the data: $\chi^{2}(120)=307.68$, $\mathrm{p} \leq 0.001$, IFI $=0.97, \mathrm{CFI}=0.97, \mathrm{TLI}=0.96, \mathrm{RMSEA}=0.05$, and Normed $\chi^{2}=2.56$.

We also tested the multidimensionality of service quality using a Rival Model Strategy, (Hair et al., 2005), which compares two alternative models, a first-order model and a second-order model (Steenkamp and van Trijp, 1991). All items of a construct load into a factor (first order); whereas all six factors reflect the six dimensions of the service quality construct (second order). The second-order model offers a better fitting in support of the multidimensionality of service quality.

In assessing reliability, we examined coefficient Alpha (Cronbach) and the Coefficient of Composite Reliability for each construct (Jöreskog, 1971). Both coefficients are above the minimum threshold of 0.70 required by Nunnally (1978) for hypothesis testing, indicating that our measures are reliable (see Table I).

\section{Table I}

Reliability Analysis

\begin{tabular}{|lcc|}
\hline VARIABLES / DIMENSIONS & CRONBACH ALPHA & $\begin{array}{c}\text { COMPOSITE RELIABILITY } \\
\text { COEFFICIENT }\end{array}$ \\
\hline Trust & 0.81 & 0.75 \\
Satisfaction & 0.80 & 0.72 \\
Service Quality: & & \\
$\quad$ Responsiveness & 0.85 & 0.76 \\
$\quad$ Security/privacy & 0.81 & 0.72 \\
Accessibility/availability & 0.71 & 0.69 \\
Usability & 0.88 & 0.80 \\
$\quad$ Accuracy & 0.72 & 0.70 \\
$\quad$ Product quality & 0.73 & 0.71 \\
\hline
\end{tabular}


We also investigate construct validity in terms of convergent validity and discriminant validity. For convergent validity, Table II shows that all measure standardized coefficients resulting from confirmatory analysis are statistically significant at $\mathrm{p}<0.01)$ and above the recommended level of 0.50 (Bagozzi and Yi, 1988; Anderson and Gerbing, 1988). Discriminant validity was assessed using two procedures, Chi-squared differences and confidence interval tests (Bagozzi, 1981; Anderson and Gerbing, 1988). Table II shows that the tested-model (see Figure 1) Chi-square is significantly different from all alternative models where two dimensions are perfectly correlated (Janssens et al., 1995). Table II also shows discriminant validity in any pair of latent variables. When estimating each pair's correlations, value " 1 " is excluded from all confidence intervals and the correlation coefficients are much below value " 1 " in support of model discriminant validity.

\section{Table II}

Validity analysis

\begin{tabular}{|lccc|}
\hline CONSTRUCT PAIRS & $\begin{array}{c}\text { CORRELATION } \\
\text { COEFFICIENT }\end{array}$ & $\begin{array}{c}\text { CHI-SQUARED } \\
\text { DIFFERENCES }\end{array}$ & $\begin{array}{c}\text { CONFIDENCE } \\
\text { INTERVALS }\end{array}$ \\
\hline TRUST-SAT & $0.75^{*}$ & $148.89(1)^{*}$ & $0.70 ; 0.81$ \\
TRUST-SQ & $0.83^{*}$ & $155.49(1)^{*}$ & $0.79 ; 0.87$ \\
SAT-SQ & $0.85^{*}$ & $100.01(1)^{*}$ & $0.82 ; 0.89$ \\
RESP-SECUR & $0.83^{*}$ & $60.35(1)^{*}$ & $0.79 ; 0.89$ \\
RESP-AC\&AV & $0.90^{*}$ & $24.69(1)^{*}$ & $0.84 ; 0.93$ \\
RESP-USAB & $0.65^{*}$ & $285.76(1)^{*}$ & $0.59 ; 0.72$ \\
RESP-ACCUR & $0.87^{*}$ & $48.38(1)^{*}$ & $0.78 ; 0.89$ \\
RESP-P QUAL & $0.84^{*}$ & $29.49(1)^{*}$ & $0.83 ; 0.93$ \\
SECUR-AC\&AV & $0.74^{*}$ & $71.46(1)^{*}$ & $0.69 ; 0.83$ \\
SECUR-USAB & $0.64^{*}$ & $195.92(1)^{*}$ & $0.60 ; 0.74$ \\
SECUR-ACCUR & $0.82^{*}$ & $43.29(1)^{*}$ & $0.77 ; 0.89$ \\
SECUR-P QUAL & $0.81^{*}$ & $58.32(1)^{*}$ & $0.73 ; 0.86$ \\
AC\&AV-USAB & $0.76^{*}$ & $71.19(1)^{*}$ & $0.73 ; 0.85$ \\
AC\&AV-ACCUR & $0.82^{*}$ & $47.68(1)^{*}$ & $0.73 ; 0.86$ \\
AC\&AV-P QUAL & $0.78^{*}$ & $45.23(1)^{*}$ & $0.71 ; 0.85$ \\
USAB-ACCUR & $0.72^{*}$ & $123.75(1)^{*}$ & $0.55 ; 0.70$ \\
USAB-P QUAL & $0.61^{*}$ & $165.88(1)^{*}$ & $0.73 ; 0.87$ \\
ACCUR-P QUAL & $0.79^{*}$ & $45.23(1)^{*}$ & $0.64 ; 077$ \\
\hline
\end{tabular}

* Significant at leve 10.01 
b. Model: SERVICE QUAlity, CUSTOMER SATISFACTION AND CUSTOMER TRUST

Exploratory factor analysis (Hair et al., 2005) and confirmatory factor analysis (Jöreskog and Sörbom, 1993) resulted in two unidimensional constructs for customer satisfaction and customer trust with reliability coefficients above 0.70 (Nunnally, 1978) (See Table III).

\section{Table III}

Confirmatory factor analysis

\begin{tabular}{|lcc|}
\hline ITEMS & $\begin{array}{c}\text { STANDARDIZED } \\
\text { COEFFICIENT (FIRST } \\
\text { ORDER) }\end{array}$ & $\begin{array}{c}\text { STANDARDIZED } \\
\text { COEFFICIENT (SECOND } \\
\text { ORDER) }\end{array}$ \\
\hline Trust 1 & $0.66^{*}$ & \\
Trust 2 & $0.80^{*}$ & \\
Trust 3 & $0.67^{*}$ & \\
Trust 4 & $0.72^{*}$ & \\
\hline Satisfaction 1 & $0.79^{*}$ & \\
Satisfaction 2 & $0.71^{*}$ & \\
Satisfaction 3 & $0.76^{*}$ & $0.75^{*}$ \\
\hline SERVICE QUALITY & & \\
\hline Responsiveness 1 & $0.71^{*}$ & $0.89^{*}$ \\
Responsiveness 2 & $0.83^{*}$ & \\
Responsiveness 3 & $0.85^{*}$ & $0.94^{*}$ \\
\hline Security/privacy 1 & $0.75^{*}$ & \\
Security/privacy 2 & $0.77^{*}$ & $0.89^{*}$ \\
Security/privacy 3 & $0.77^{*}$ & \\
\hline Accessibility/availability 1 & $0.70^{*}$ & \multirow{2}{*}{$0.93^{*}$} \\
Accessibility/availability 2 & $0.84^{*}$ & \\
Accessibility/availability 3 & $0.55^{*}$ & \multirow{2}{*}{$0.90^{*}$} \\
\hline Usability 1 & $0.83^{*}$ & \\
Usability 2 & $0.89^{*}$ & \\
Usability 3 & $0.80^{*}$ & \\
\hline Accuracy 1 & $0.78^{*}$ & \\
Accuracy 2 & $0.51^{*}$ & $0.70^{*}$ \\
Accuracy 3 & $0.78^{*}$ & \\
\hline Product Quality 1 & $0.76^{*}$ & \\
Product Quality 2 & $0.55^{*}$ & \\
Product Quality 3 & & \\
\hline
\end{tabular}

* Significant at level 0.01 
Confirmatory factor analysis applied to the entire measurement model shows good fit to the data: $\chi^{2}(266)=760.11, \mathrm{p} \leq 0.001$; $\mathrm{NFI}=0.92 ; \mathrm{IFI}=0.94 ; \mathrm{CFI}=0.94 ; \mathrm{GFI}=0.91 ; \mathrm{RMSEA}=0.05$; Normed $\chi^{2}=3.13$.

Convergent validity applied to the model shows that all measure standardized coefficients are statistically significant at $\mathrm{p}<0.01$ ) and above the recommended level of 0.50 (Bagozzi and Yi, 1988; Anderson and Gerbing, 1988). Similarly, discriminant validity procedures show that the theoretical model is significantly different from all alternative models and that the correlation coefficients are much below value " 1 " in support of model discriminant validity (See Table II).

\section{B. Hypothesis Testing}

Hypotheses tests using structural equation modeling are based on a measurement model with good fit to the data: $\chi^{2}(267)=805.55$, $\mathrm{p} \leq 0.001 ; \mathrm{NFI}=0.91 ; \mathrm{IFI}=0.94 ; \mathrm{CFI}=0.94 ; \mathrm{GFI}=0.91$; $\mathrm{RMSEA}$ $=0.06$; and Normed $\chi^{2}=3.02$. Figure 1 depicts the model relationships according to which service quality positively and significantly affects customer satisfaction with Internet services in support of hypothesis 2. In turn, customer satisfaction positively and significantly affects customer trust corroborating hypothesis 1 .

From a broader perspective, the model tests also show that customer satisfaction is a mediating variable between service quality and customer trust. Service quality has an indirect effect on customer trust as hypothesized and tested. 


\section{Figure 1}

Structural model: customer trust in Internet banking

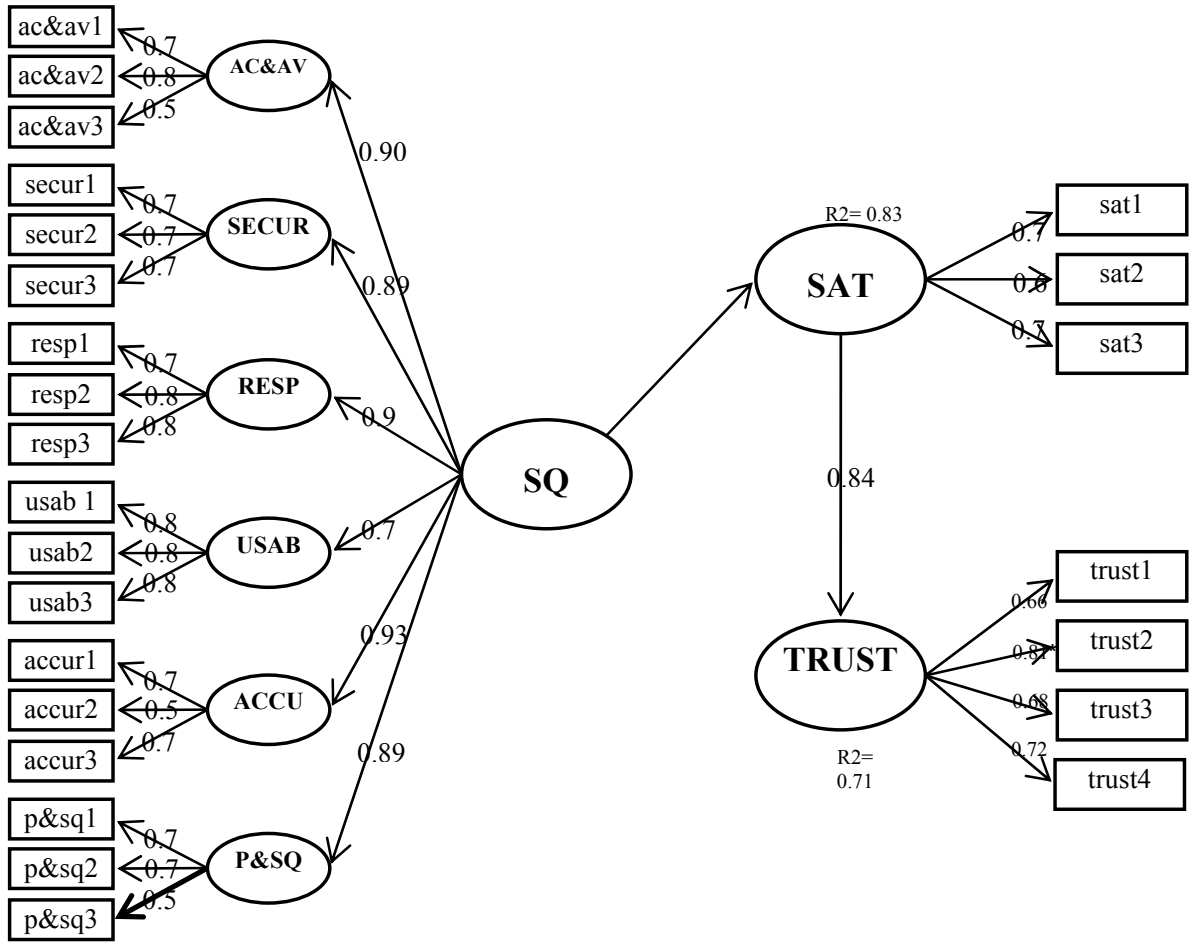

* Significant at level 0.01

\section{Analyses of Rival Models}

An analysis of rival models probes the robustness of the proposed model (Bloemer and Odekerken-Schröder, 2003). Two rival models are used: (a) the first model probes if in fact customer satisfaction mediates the relationship between service quality and customer trust in Internet banking; (b) the second model probes the robustness of a second-order service quality in its impact on the outcomes versus the impact of each dimension separately. 


\section{Figure 2}

Rival Models

(a) Rival model: Service quality as a multidimensional construct

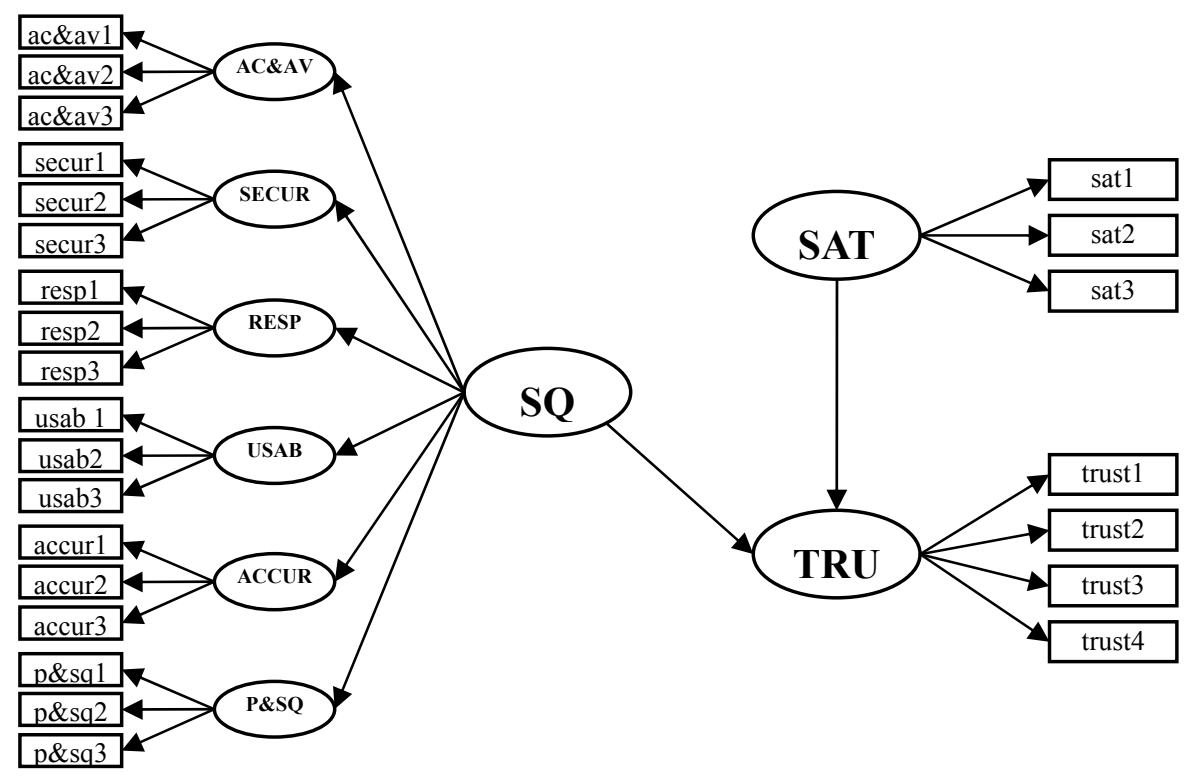

(a) Regarding the first rival model, structural equation results applied to both models show that the tested model is superior to this rival model because it better fulfills the requirements proposed by Morgan and Hunt (1994) and shows higher values of CFI (0.94 versus 0.89 for the rival model, where only the first value is above the threshold of 0.90 (Bansal and Boyer, 2000), greater explanatory power $(\mathrm{R} 2=0.71$ for the tested model versus $\mathrm{R} 2=0.62$ for the rival model), and a smaller Normed $\chi 2$ (3.02 versus 4.66$)$. The tested model is a better fit for the data than the rival model and is more parsimonious. Thus, it is concluded that the relationship between service quality and customer trust in Internet banking is mediated by the customer satisfaction with the Internet offerings. 
The Effects of Service Quality on Customer Trust...
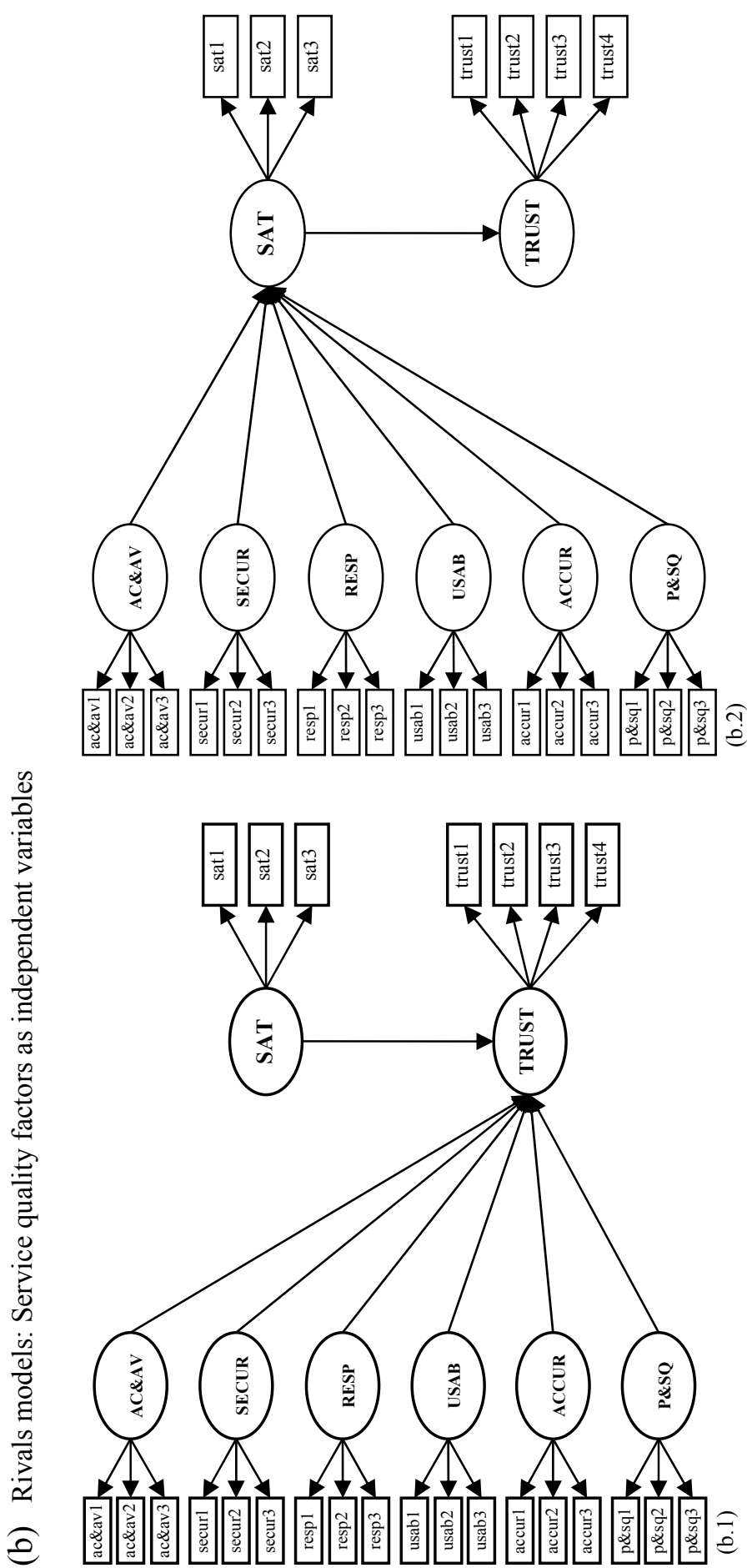
(b) Regarding the second rival model, the CFI from the alternative models b. 1 and b. 2 are 0.64 y 0.69 respectively, lower than the CFI from the proponed model $(0.94)$ and much lower than the required value. Similarly, the resulting R2 are 0.54 and 0.51 for the alternative models b.1 and b.2, respectively, which are lower than the R2 $(0.71)$ for the proposed model. Finally, the values from the Normed $\chi 2$ test are 12.94 and 11.28 , respectively, which are outside the required range $([1 ; 5])$. Thus, it is concluded that the proposed model fits the data better, explains more, and is parsimonious. The proposed model establishes a significant and positive relationship between customer satisfaction and customer trust, and examines the significant and positive impact of a second-order service quality on customer satisfaction.

\section{Conclusions and managerial implications}

This study explored the role that service quality plays in the generation of customer trust in online banks. The results of this study demonstrate that service quality plays a vital role in the generation of trust, and that the effect of service quality is direct on customer satisfaction and indirect on customer trust. The indirect effect on trust is mediated by customer satisfaction. More importantly, the findings point to service quality's role in this context as being a multidimensional construct, not a group of isolated, independent influences, as previous studies have shown.

Service quality is a latent variable (a second-order construct), where each of its dimensions interacts with the others. Therefore, the potential effect of each dimension on trust is influenced by the other components of service quality. This study contributes with findings and evaluations supporting a sixdimension construct of service quality: security/privacy, accessibility/availability, usability, respon-seveness, accuracy, and product quality. 
These results have important implications for the management of online banks. In accordance with the results of this study, management of consumer trust in this type of banking must treat different factors of service quality as interrelated whole, not as separate and unrelated, as other studies have proposed.

The implications for the practice are straight forward. Banks may not only appreciate the importance of customer trust in the generation and sustenance of Internet services, they can also trace the origin of trust back to its sources, fundamentally customer satisfaction and service quality. In addition, they can follow a path that allows them to place their resources appropriately by, first, securing service quality in tandem in order to produce customer satisfaction and, then, using customer satisfaction as leverage to attain customer trust. In securing service quality in tandem, banks should pay attention not only to the products and services offered via Internet, but also to the delivery process and the potential problems created when not reaching customer expectations. Once customer satisfaction is secured, banks can reasonably expect to obtain the derived benefit of satisfaction, customer trust.

More specifically, banks have to work on the elements that make service quality appreciated by the customer, as reflected in the six quality dimensions identified and corroborated in the study. A key element is structural security of the web site, including protection of customers' personal information (Casaló et al., 2007; McKnight et al., 2002). Another customer-driven element is web accessibility and availability, including useful content and dynamic interfaces. Internet bank users expect to experience an errorless registration process for transactions (accuracy) and to easily understand the structure of the web site, its functions, interfaces, and the contents offered (responsiveness). They also favor usability or perceived ease of site navigation involving both time required and action necessary to obtain the desired results, and speed in finding what they are looking for on the web site. 
Bank managers should understand that Internet banking is not only a technological tool, it is a path to reach and secure customers, who in turn expect service quality, as characterized in this study, and satisfaction, as preconditions to customer's trust in ebanking.

\section{References}

AL-HAWARI M. and T. WARD (2006), "The effect of automated service quality on Australian banks' financial performance and the mediating role of customer satisfaction", Marketing Intelligence \& Planning, Vol. 24, № 2, pp. 127-147.

ANDERSON J.C. and D.W. GERBING (1988), "Structural equation modeling in practice: a review and Recommended Two-Step Approach", Psychological Bulletin, Vol. 103, No 3, pp. 411-423.

ANDERSON R.E. and S.S. SRINIVASAN (2003), "E-satisfaction and e-loyalty: a contingency framework", Psychology \& Marketing, Vol. 20, $\mathrm{N}^{\mathrm{o}} 2$, pp. 123-138.

BAGOZZI, R.P. (1981), "Evaluating structural equations models with unobservable variables and measurement error: a comment", Journal of Marketing Research, Vol. 18, № 3, pp. 375-381.

BAGOzZI, R.P. and Y. YI, (1988), "On the evaluation of structural equation models", Journal of the Academy of Marketing Science, Vol. 16, No. 1, pp. 74-95.

BANSAL, H.S. and P.A. BOYER (2000), "Word-of-mouth processes within a services purchase decision context", Journal of Service Research, Vol. 3, $\mathrm{N}^{\mathrm{o}} 2$, pp. 166-177.

Bansal, H.S., McDougall, G.H.G., Dikolli, S.S. and K.L. Sedatole, K (2004), "Relating e-satisfaction to behavioral outcomes: an empirical study", Journal of Services Marketing, Vol. 18, № 4, pp. 290-302.

BARNES, S.J. and R.T. VIDGEN (2002), "An integrative approach to the assessment of e-commerce quality" , Journal of Electronic Commerce Research, Vol. 3, No 3, pp. 114-127. 
BAUER, H.H., HAMMERSCHMIDT, M. and T. Falk (2005), "Measuring the quality of e-banking portals", International Journal of Bank Marketing, Vol. 23, $\mathrm{N}^{\mathrm{o}} 2$, pp. 153-175.

Bitner, M.J., BoOMs, B.H., and M.S. Tetreault (1990), "The service encounter: diagnosing favorable and unfavorable incidents", Journal of Marketing, Vol. 54, $\mathrm{N}^{\mathrm{o}}$ 1, pp. 71-84.

BloEMER, J. and G. ODEKERKEN-SCHRÖDER (2003), "Antecedents and consequences of affective commitment", Australasian Marketing Journal, Vol. 11, № 3, pp. 33-43.

BROCKMAN, B.K. (1998), "The influence of affective state on satisfaction ratings", Journal of Consumer Satisfaction, Dissatisfaction and Complaining Behavior, Vol. 11, pp. 40-50.

BROWN, I.J. and M. BuYs (2005), "Customer satisfaction with internet banking web sites: an empirical test and validation of a measuring instrument", South African Computer Journal, Vol. 35, pp. 29-37.

CÁCERES, R.C. and N.G. PAPAROIDAMIS (2007), "Service quality, relationship satisfaction, trust, commitment and business-to-business loyalty", European Journal of Marketing, Vol. 41, No 7/8, pp. 836-867.

CARMAN, J.M. (1990), “Consumer perceptions of service quality: an assessment of the SERVQUAL dimensions", Journal of Retailing, Vol. 66, № 1 , pp. 33-35.

Casaló, L.V., Flavián, C. and M. Guinalíu (2007), "The role of security, privacy, usability and reputation in the development of online banking", Online Information Review, Vol. 31, № 5, pp. 583-603.

CHA, S.K., KIM, M. and R. MCNIEL (2005), "Diffusion of Internet-based financial transactions among customers in South Korea", Journal of Global Marketing, Vol. 19, No 2, pp. 95-111.

COX, J.L. and B.G. DALE (2001), "Service quality and e-commerce: an exploratory analysis", Managing Service Quality, Vol. 11, No 2, pp. 121-131.

CRONIN, J.J. and S.A. TAYLOR (1992), "Measuring service quality: a reexamination and extension," Journal of Marketing, Vol. 56, $\mathrm{N}^{\circ} 3$, pp. 55-69. 
Crosby, L.A., Evans, K.A. and D. Cowles (1990), "Relationship quality in services selling: an interpersonal influence perspective", Journal of Marketing, Vol. 54, No 3, pp. 68-81.

DANNENBerG, M. and D. Kellner (1998), "The bank of tomorrow with today's technology", International Journal of Bank Marketing, Vol. 16, $\mathrm{N}^{\mathrm{o}} 2$, pp. 90-97.

DE RUYTER, K. and J. Bloemer (1997), "Merging service quality and service satisfaction: an empirical test of an integrative model", Journal of Economic Psychology and Marketing, Vol. 18, No 4, pp. 387-406.

DE Wulf, K. and G. ODEKERKEN-SCHRÖDER (2003), "Assessing the impact of a retailer's relationship efforts on consumer' attitudes and behavior", Journal of Retailing and Consumer Services, Vol. 10, No 2, pp. 95-108.

DimitriadeS, Z.S. (2006), "Customer satisfaction, loyalty and commitment in service organizations: some evidence from Greece", Management Research News, Vol. 29, № 12, pp. 782-800.

DONEY, P. and J.P. CANNON (1997), "An examination of the nature of trust in buyer-seller relationships", Journal of Marketing, Vol. 61, N 2 , pp. $35-51$

Evanschitzky, H., IYer, G.R., Hesse, J. and D. AhLert (2004), "E-satisfaction: a re-examination", Journal of Retailing, Vol. 80, pp. 239-247.

Flavián, C., GuinalíU, M. and R. GuRREA (2006), “The role played by perceived usability, satisfaction and consumer trust on website loyalty", Information \& Management, Vol. 43, pp. 1-14.

FloH, A. and H. TREIBLMAIER (2006), "What keeps the e-banking customer loyal? A multigroup analysis of the moderating role of consumer characteristics on e-loyalty in the financial service industry", Journal of Electronic Commerce Research, Vol. 7, № 2, pp. 97-110.

Gefen, D., Karahanna, E. and D.W. Straub (2003), “Trust and TAM in online shopping: an integrated model”, MIS Quarterly, Vol. 27, No 1, pp. 51-90.

GeYsKens, I., SteEnKAMP, J.B.E. and N. KumAR (1999), "A meta-analysis of satisfaction in marketing channel relationship", Journal of Marketing Research, Vol. 36, No 2, pp. 223-238. 
Gounaris, S.P., Stathakopoulos, V. and A.D. Athanassopoulos (2003), "Antecedent to perceived service quality: an exploratory study in the banking industry", International Journal of Bank Marketing, Vol. 21, $\mathrm{N}^{\circ} 4$, pp. 168-190.

GraZiOli, S. and S.L. JARVENPAA (2000), "Perils of internet fraud: an empirical investigation of deception and trust with experienced internet", IEEE Transactions on Systems, Man and Cybernetics - Part A: Systems and Humans, Vol. 30, No 4, pp. 395-410.

GRÖNROOS, C. (1984), “A service quality model and its marketing implications", European Journal of Marketing, Vol. 18, № 4, pp. 36-44.

Hair, J.F., Black, W.C., Babin, B., Anderson, R.E. and R.L. TAtham (2005), Multivariate Data Analysis, 6th edition, Prentice-Hall International, London, UK.

HARRIS, L.C. and M.M.H. GoODE (2004), "The four levels of loyalty and the pivotal role of trust: a study of online service dynamics", Journal of Retailing, Vol. 80, pp. 139-158.

Hirose, Y. and N. SoneHARA (2008), "Management of information-credibility risk in an ICT society: A social implementation", Internet Research, Vol. 18, No 2, pp. 142-154.

HitT, L., XUE, M. and P.Y. CHEN (2008), "The determinants and outcomes of Internet banking adoption", MSI Report $N^{o}$ 07-122, Marketing Science Institute, Cambridge, MA.

HOWCROFT, B. and M. DURKIN (2000), "Reflections on bank-customer interactions in the new millennium", Journal of Financial Services Marketing, Vol. 5, $\mathrm{N}^{\mathrm{o}}$ 1, pp. 9-20.

HuMPHREYS, K. (2000), "Internet banking: leveling the playing field for community banks", in Keyes, J. (Ed.), Financial Services Information Systems, $2^{\text {nd }}$ ed, Auerbach, Boca Raton, FL.

HWAN, Y. and D.J. KIM (2007), "Customer self-service systems: the effects of perceived web quality with service contents on enjoyment, anxiety, and e-trust”, Decision Support Systems, Vol. 43, pp. 746-760. 
JANDA, S., Trocchia, P.J. and K.P. GWINNER (2002), "Consumer perceptions of internet retail service quality", International Journal of Service Industry Management, Vol. 13, № 5, pp. 412-431.

Janssens, M., Brett, J. and Smith, F. (1995), “Confirmatory cross-cultural research: testing the viability of a corporation-wide safety policy", Academy of Management Journal, Vol. 38 No. 2, pp. 64-382.

JARVENPAA, S.L. and N. TRACTINSKY (1999), "Consumer trust in an internet store: a cross-cultural validation", Journal of Computer-Mediated Communication Online, Vol. 5, $\mathrm{N}^{\mathrm{o}}$ 2, pp. 1-35.

JÖRESKOG, K.G. (1971), "Statistical analysis of sets of co-generic test", Psycometrika, Vol. 36, pp 109-133.

JÖRESKOG, K.G. and D. SÖRBOM (2001), New feature in LISREL 8, Scientific Software, Chicago, USA.

JUN, M. and S. CAI (2001), "The key determinants of internet banking service quality: a content analysis", International Journal of Bank Marketing, Vol. 19, No 7 , pp. 276-291.

KATO, Y., KUROHASHI, S. and K. INUI (2008), "Information credibility on the web", Internet Research, Vol. 18, No 2, pp. 204-209.

KetTingeR, W.J. and C.C. LEE (1999), "Replication of measures of information systems research: the case of IS SERVQUAL", Decision Sciences, Vol. 30, No 3, pp. 893-899.

KIM, D.J., FERRIN, D.L. and H.R. RAO (2008),“A trusted-based consumer decision-making model in electronic commerce: the role of trust, perceived risk, and their antecedents", Decision Support Systems, Vol. 44, pp. 544-564.

KiM, K.K. and B. PrabhaKAR (2004), "Initial trust and the adoption of B2C e-commerce: the case of internet banking", Database for Advances in Information Systems, Vol. 35, $\mathrm{N}^{\mathrm{o}} 2$, pp. 50-65.

Kracher, B., Corritone, C.L. and S. Wiedenbeck (2005), “A foundation for understanding online trust in electronic commerce", Information, Communication \& Ethics in Society, Vol. 3, № 3, pp. 131-141. 
Kumar, N., ScheER, L.K. and J.B.E. STEENKAMP (1995), “The effects of supplier fairness on vulnerable resellers", Journal of Marketing Research, Vol. 32, $\mathrm{N}^{\mathrm{o}} 1$, pp. 54-65.

LeE, H., LEE, Y. and D. Yoo (2000), “The determinants of perceived service quality and its relationship with satisfaction", Journal of Services Marketing, Vol. 14, № 2/3, pp. 217-231.

LiAO, C., PALVIA, P. and H.N. LIN (2006), "The roles of habit and web site quality in e-commerce", International Journal of Information Management, Vol. 26, pp. 469-483.

Lichtenstein, D.R., Netemeyer, R.G. and S. Burton (1990), "Distinguishing coupon proneness from value consciousness: an acquisition-transaction utility theory perspective", Journal of Marketing, Vol. 54, N ${ }^{\circ}$ 3, pp. 54-67.

Lin, H.X., Choong, Y.Y. and G. SAlvendy (1997), "A proposed index of usability: a method for comparing the relative usability of different software systems", Behavior and Information Technology, Vol. 16, $\mathrm{N}^{\mathrm{o}} 4 / 5$, pp. $267-278$.

LIU, C. and K.P. ARNETT (2000), "Exploring the factor associated with web site success in the context of electronic commerce", Information \& Management, Vol. 38, No 1, pp. 23-34.

LiU, C., Marchenwka, J.T., LU, J. and C.S. Yu (2005), "Beyond concern: a privacy-trust-behavioral intention model of electronic commerce", Information \& Management, Vol. 42, pp. 289-304.

LoiAcono, E.T., WATSON, R.T. and D.L. GoOdHUE (2007), "WebQual: an instrument for consumer evaluation of web sites", International Journal of Electronic Commerce, Vol. 11, № 3, pp. 51-87.

LÓPEZ, J.M. (2001), "Banca por internet: evolución, situación actual y retos de futuro", Revista del Instituto de Estudios Económicos, Vol. 1/2, pp. 335-355.

MACINTOSH, G. and L.S. LOCKSHIN (1997),"Retail relationships and store loyalty: a multi-level perspective", International Journal of Research in Marketing, Vol. 14, № 5, pp. 487-497. 
MADU, C.N. and A.A. MADU (2002), "Dimensions of e-quality", International Journal of Quality \& Reliability Management, Vol. 19, N³, pp. 246-258.

MAHAJAN, V., SRINIVASAN, R. and J. WIND (2002), "The dot.com retail failures of 2000: were there any winners?", Journal of the Academy of Marketing Science, Vol. 30, No 4, pp. 474-486.

MAQUedA, F.J. and J.I. LlaGUNO (1995), Marketing estratégico para empresas de servicios, Ed. Díaz de Santos, Madrid.

MCKNight, D.H. and N.L. ChERVANY (2001), "What trust means in e-commerce customer relationships: an interdisciplinary conceptual typology", International Journal of Electronic Commerce, Vol. 6, $\mathrm{N}^{\mathrm{o}}$ 2, pp. 35-59.

MCKnight, D.H., Choudhury, V. and C. KACMAR (2002), "The impact of initial consumer trust on intentions to transact with a web site: a trust building model", Journal of Strategic Information Systems, Vol. 11, pp. 297-323.

MOLS, N.P. (1999), “The internet and the banks' strategic distribution channel decisions", International Journal of Bank Marketing, Vol. 17, N 6/7, pp. 295-300.

Moorman, C., Zaltman, G. and R. Deshrande (1992), "The relationship between providers and users of market research: the dynamics of trust within and between organizations", Journal of Marketing Research, Vol. 29, No 3, pp. 314-328.

MORGAN, R.M. and S.D. HunT (1994), "The commitment-trust theory of relationship marketing", Journal of Marketing, Vol. 58, No 3, pp. 20-38.

NohriA, N. and R.G. ECCLES (1992), "Face-to-face: making network organizations work", in Nohria, N. and Eccles, R.G. (Eds.), Networks and Organizations, Harvard Business School Press, Boston, MA, pp. 288-308.

NunNaly, J.C. (1978), Psychometric Theory, McGraw-Hill, New York.

OLIVER, R.L. (1997), Satisfaction: a behavioral perspective on the consumer, McGraw-Hill, New York.

OLIVER, R.L. (1999) “Whence consumer loyalty?”, Journal of Marketing, Vol. 63, No 4, pp. 33-44. 
Papadopoulou, P., Andreou, A., Kanellis, P. and D. Martakos (2001), "Trust and relationship building in electronic commerce", Internet Research, Vol. 11, № 4, pp. 322-332.

PARASURAmAn, A., ZeithamL, V.A. and L.L. Berry (1988), "SERVQUAL: a multi-item scale for measuring consumer service quality" Journal of Retailing, Vol. 64, Nº 1, pp. 12-37.

Parasuraman, A., Zeithaml, V.A. and A. Malhotra (2005), "E-S-Qual: a multiple-item scales for assessing electronic service quality", Journal of Service Research, Vol. 7, № 3, pp. 213-233.

PAVLOU, P.A. (2003), "Consumer acceptance of electronic commerce: integrating trust and risk with the technology acceptance model" International Journal of Electronic Commerce, Vol. 7, No 3, pp. 101-134.

Prescott, M.B. and C. VAn SLyKe, C. (1997), "Understanding the internet as an innovation”, Industrial Management \& Data Systems, Vol. 97, № 3, pp. 119-124.

Ranganathan, C. and S. Ganapathy (2002), "Key dimensions of B2C web sites", Information \& Management, Vol. 39, Nº 6, pp. 457-465.

RATNASINGHAM, P. (1998), "The importance of trust in electronic commerce", Internet Research, Vol. 8, No 4, pp. 313-321.

REIBSTEIN, D.J. (2002), "What attracts customers to online stores, and what keeps them coming back?", Journal of the Academy of Marketing Science, Vol. 30, No 4, pp. 465-473

RibBink, D., VAN Riel, A.C.R., LiLJANDer, V. and S. Streukens (2004), "Comfort your online customer: quality, trust and loyalty on the internet", Managing Service Quality, Vol. 14, Nº, pp. 446-456.

Roy, M.C., Dewit, O. and B.A. AuberT (2001), "The impact of interface usability on trust in web retailers", Internet Research, Vol. 11, $\mathrm{N}^{\circ} 5$, pp. $388-398$.

RUST, R.T. and K.N. LEMON (2001), "E-service and the consumer", International Journal of Electronic Commerce, Vol. 5, No 3, pp. 85-101. 
SAnZo, M.J., SAntos, M.L., VÁsques, R. and L.I. ÁlVAREz (2003), "The effect of market orientation on buyer-seller relationship satisfaction", Industrial Marketing Management, Vol. 32, № 4, pp. 327-345.

SELNES, F. (1993), “An examination of the effect of product performance on brand reputation, satisfaction and loyalty", European Journal of Marketing, Vol. 27, $\mathrm{N}^{\mathrm{o}}$ 9, pp. 19-35.

SELNES, F. (1998), “Antecedents and consequences of trust and satisfaction in buyer-seller relationship", European Journal of Marketing, Vol. 32, $\mathrm{N}^{\mathrm{o}} 3 / 4$, pp. 305-322.

Shankar, V., SMith, A.K. and A. RANGaswamy (2003), "Customer satisfaction and loyalty in online and offline environments", International Journal of Research in Marketing, Vol. 20, No 2, pp. 153-175.

Sharma, N. and P.G. PATTERSON (1999), "The impact of communication effectiveness and service quality on relationship commitment in consumer, professional services", Journal of Services Marketing, Vol. 13, No $2 / 3$, pp. 151-170.

Sharma, N. and P.G. PATterson (2000), "Switching costs, alternative attractiveness and experience as moderators of relationship commitment in professional, consumer services", International Journal of Service Industry Management, Vol. 11, No 5, pp. 470-490.

SMITH, J.B. and D.W. BARCLAY (1997), "The effects of organizational differences and trust on the effectiveness of selling partner relationships", Journal of Marketing, Vol. 61, No 1, pp. 3-21.

SOHAIL, M.S. and N.M. SHAIKH (2008), "Internet banking and quality of service: perspective from a developing nation in the Middle East", Online Information Review, Vol. 32, No 1, pp. 58-72.

SOlOMON, R.C. and F.L. Flores (2001), Building trust in business, politics, relationships, and life, Oxford University Press, Oxford.

STEENKAMP, J.B.E. and VAN H.C.M TRIJP (1991), "The use of LISREL in validating marketing constructs", International Journal of Research in Marketing, Vol. 8, No 4, pp. 283-299. 
SUH, B. and I. HAN (2002), "Effect of trust on customer acceptance of internet banking", Electronic Commerce Research and Applications, Vol. 1, No. 3/4, pp. 247-263.

SzYMANSKI, D.M. and R.T. HiSE (2000), "E-satisfaction: an initial examination", Journal of Retailing, Vol. 76, No 3, pp. 309-322.

TORRES, E., HidAlGO, P. and C. BARRA (2008), "Determination and categorization of the satisfaction and dissatisfaction factors in the Internet banking" Academia, Vol. 41, pp. 29-46.

Urban, G.L., Sultan, F. and W.J. Qualls (2000), "Placing trust at the center of your internet strategy", Sloan Management Review, Vol. 42, No. 1, pp. 39-48.

VAn Riel, A.C.R., LemminK, J., Streukens, S. and V. Liljander (2004), "Boost customer loyalty with online support: the case of mobile telecoms providers", International Journal of Internet Marketing and Advertising, Vol. 1, No 1, pp. 4-23.

VAN RIEL, A.C.R., LILJANDER, V. and P. JURRIËNS (2001), "Exploring customer evaluations of e-services: a portal site", International Journal of Service Industry Management, Vol. 12, ${ }^{\circ} .4$, pp. 359-377.

Veloutsou, C., Daskou, S. and A. Daskou (2004), “Are the determinants of bank loyalty brand specific?", Journal of Financial Services Marketing, Vol. 9, No 2, pp. 113-125.

WAlczuCH, R. and H. LundGREN (2004), "Psychological antecedents of institution-based consumer trust in e-retailing", Information \& Management, Vol. 42, No 1, pp. 159-177.

Wolfinbarger, M. and M.C. Gilly (2003), "eTailQ: dimensionalizing, measuring and predicting etail quality", Journal of Retailing, Vol. 79, $\mathrm{N}^{\circ} 3$, pp. 183-198.

YANG, Z., CAI, S., ZHOU, Z. and N. ZHOU (2005), "Development and validation of an instrument to measure user perceived service quality of information presenting web portals", Information \& Management, Vol. 42, № 4 , pp. 575-589. 
YIU, C.S., GRANT, K. and D. EDGAR (2007), "Factor affecting the adoption of internet banking in Hong Kong - implications for the banking sector", International Journal of Information Management, Vol. 27, pp. 336-351.

Yoo, B. and N. DONTHU (2001), "Developing a scale to measure the perceived service quality of internet shopping sites (Sitequal)", Quarterly Journal of Electronic Commerce, Vol. 2, No 1, pp. 31-47.

YoON, S.J. (2002), "The antecedents and consequences of trust in online-purchase decisions", Journal of Interactive Marketing, Vol. 16, № 2, pp. 47-63.

ZAICHKOWSKY, J.L. (1985), "Measuring the involvement construct", Journal of Consumer Research, Vol. 12, No 3, pp. 341-352.

Zeithaml, V.A., Berry, L.L. and A. PARAsuraman (1996), "The behavioral consequences of service quality", Journal of Marketing, Vol. 60, $\mathrm{N}^{\mathrm{o}} 2$, pp. 31-46.

Zeithaml, V.A., Parasuraman, A. and A. Malhotra (2000), “A conceptual framework for understanding e-service quality: implications for future research and managerial practice", Report No. 00-115, Marketing Science Institute, Cambridge, MA.

Wong, A. and A. DEAn (2009), "Enhancing value for Chinese shoppers: The contribution of store and customer characteristics", Journal of Retailing and Consumer Services, Vol. 16(2), pp. 123-134. doi:10.1016/j.jretconser.2008.11.004.

WU, P.C.S., G.Y.-Y. YEH and C.-R. HSIAO (2011), "The effect of store image and service quality on brand image and purchase intention for private label brands", Australasian Marketing Journal (AMJ), Vol. 19(1), pp. 30-39. doi:10.1016/j.ausmj.2010.11.001

Zielke, S. and T. DobBelstein (2007), "Customers' willingness to purchase new store brands", Journal of Product \& Brand Management, Vol. 16(2), pp. 112-121. 